\title{
PENGARUH BAURAN PEMASARAN TERHADAP KEPUASAN \\ DAN LOYALITAS PELANGGAN PADA KLINIK KECANTIKAN FELISA SKIN CARE DI RENGAT KABUPATEN INDRAGIRI HULU
}

\author{
Akbar Surya Atmaja ${ }^{1}$, Zulkarnain $^{2}$, Kasman Arifin $^{3}$ \\ ${ }^{1)}$ Mahasiswa Program Pasca Sarjana Manajemen Universitas Riau \\ 2) 3) Dosen Pascasarjana Fakultas Ekonomi Universitas Riau \\ Email : akbarsuryatmaja@gmail.com ${ }^{1}$
}

\begin{abstract}
Effect of Marketing Mix on Customer Satisfaction and Loyalty in Felisa Skin Care Beauty Clinic in Rengat, Indragiri Hulu Regency.This study aims to see and know the direct and indirect effects of the Marketing Mix on Customer Satisfaction and Loyalty. The population in this study were all customers of the Beauty Clinic Felisa Skin Care Rengat Branch and Belilas Branch with a total of 496 people and determine the number of samples using the Slovin method to obtain 221 people. The results of this study found that the marketing mix affects Consumer Satisfaction and Marketing Mix influences customer Loyalty through Satisfaction.
\end{abstract}

Keywords: Product, Price, Place, Promotion, People, Physical Evidence, Process, Customer Satisfaction and Loyalty.

\section{PENDAHULUAN}

Nilai dan hubungan pelanggan merupakan inti utama strategi dan program pemasaran, untuk menemukan strategi bauran pemasaran dan menetapkannya menjadi tindakan yang bertujuan mendapatkan nilai pelanggan, pemasar harus mengetahui langkahlangkahnya: a). Pemasar Harus memahami pasar dan kebutuhan serta keinginan pelanggan. b). Pemasar merancang strategi pemasaran yang digerakkan pelanggan dengan tujuan mendapatkan, mempertahankan, dan menumbuhkan pelanggan sasaran. c).Pemasar membangun program pemasaran yang benar-benar memberikan nilai unggul. d). Membangun hubungan pelanggan yang menguntungkan. e). Perusahaan mendapatkan hasil dari hubungan pelanggan yang kuat dengan menangkap nilai dari pelanggan. (Kotler dalam Mulkan, 2016:2)
Perkembangan zaman dan teknologi yang semakin maju mengakibatkan kebutuhan masyarakat saat ini semakin meningkat. Masyarakat tidak hanya memikirkan kebutuhan akan sandang, pangan dan papan, namun masyarakat sudah mulai memikirkan kebutuhan lainnya, seperti kebutuhan akan penampilan, kecantikan dan sebagainya.

Kebutuhan wanita akan fasilitas kesehatan dan kecantikan saat ini terus meningkat, karena wanita sudah menyadari begitu pentingnya kesehatan tubuh dan merawatnya agar terlihat cantik dan sehat. Kondisi inilah yang antara lain menyebabkan tumbuh dan berkembangnya jasa yang bergerak di industri kecantikan.

Dahulu, perawatan kecantikan yang dilakukan kaum wanita masih menggunakan bahan-bahan tradisional seperti membuat masker wajah dari buah-buahan. Saat ini 
sudah ada salon kecantikan dan klinik kecantikan tempat untuk mempercantik diri. Adapun perbedaan antara klinik kecantikan dan salon kecantikan, adalah klinik kecantikan menggunakan tenaga medis (dokter umum/dokter spesialis) sedangkan salon kecantikan tenaga pelaksananya adalah ahli kecantikan (beautician).

Pertumbuhan industri kecantikan di Provinsi Riau saat ini sangat maju dan cepat. Hal ini ditandai dengan bermunculannya salon kecantikan atau klinik kecantikan sebagai salah satu sarana untuk memenuhi kebutuhan masyarakat. Beberapa klinik kecantikan yang ada di Provinsi Riau diantaranya Erha Clinic, Natasha Skin Care, Klinik Kecantikan Puspa, Aira, Klinik Kusuma dan masih banyak lagi.

Bagi masyarakat yang berada di Rengat, perawatan kecantikan yang dilakukan selama ini baru sebatas kepada penggunaan Produk Kecantikan yang bisa di peroleh di toko kosmetik atau melalui pembelian Scara Online. Dengan ketidak tahuan masyarakat tentang kandungan bahan berbahaya yang mungkin saja ada pada produk kecantikan yang di beli, maka hal ini sangat berbahaya bagi kesehatan, karena bisa mengakibatkan gangguan kulit, seperti alergi, jerawat dan Flek wajah yang semakin banyak, hingga kangker kulit.

Untuk perawatan, masyarakat Rengat biasa melakukannya di Klinik-klinik kecantikan yang ada di kota Pekanbaru, yang tentu saja hanya dapat dilakukan oleh golongan tertentu yang dikarenakan jarak yang jauh serta biaya yang mahal.

Klinik Kecantikan merupakan perusahaan yang menghasilkan produk berupa jasa layanan maupun jasa penjualan yang harus dipasarkan kepada konsumen, maka dalam memilih sebuah klinik kecantikan sebagai tempat untuk perawatan kesehatan dan kecantikan kulit, konsumen banyak dipengaruhi oleh beberapa faktor, diantaranya adalah faktor marketing Mix/Bauran Pemasaran, yang terdiri dari 7P ( yang meliputi : Produk, price, promotion, place, participant, proses, dan physical avidance).

Menurut Philip Kotler (2009:25)

Bauran pemasaran adalah suatu pendekatan pokok yang akan digunakan oleh unit bisnis dalam mencapai sasaran yang telah ditetapkan terlebih dahulu yang mana didalamnya tercantum keputusankeputusan pokok mengenai target pasar, penempatan produk di pasar, strategi pemasaran dan tingkat biaya pemasaran yang dibutuhkan. Sementara itu, Brigham dan Houston dalam Wandi (2016:21) mengatakan penjualan perusahaan secara tidak langsung akan mempengaruhi lingkungann perusahaan. Apabila penjualan perusahaan berada pada taraf yang baik dan menguntungkan maka diharapkan tingkat harapan dan kepercayaan karyawan terhadap perusahaan juga akan meningkat, dan apabila harapan dan kepercayaan terhadap perusahaan meningkat maka akan timbul perasaan memiliki perusahaan. Ketika karyawan merasa memiliki perusahaan maka kinerja karyawan akan meningkat. Salah satu indikator tingkat kesehatan perusahaan adalah tingkat penjualan perusahaan tersebut, sehingga penjualan merupakan elemen non manajerial yang paling penting bagi perusahaan.

Felisa Skin Care merupakan salah satu klinik kecantikan yang berada di Rengat, Indragiri Hulu, 
Provinsi Riau. Klinik ini menjadi salah satu alternatif bagi masyarakat Indragiri Hulu, khususnya kaum perempuan untuk melakukan perawatan wajah, sehingga tidak perlu keluar kota untuk melakukan Perawatan. Produk perawatan yang disediakan termasuk lengkap dengan harga yang terjangkau. Berbagai produk perawatan wajah dan tubuh disediakan oleh Klinik Kecantikan Felisa Skin Care guna memenuhi kebutuhan konsumennya.

Tabel 1 : Jumlah Kunjungan Pasien Klinik Kecantikan Felisa Skin Care Tahun 2015 - 2018

\begin{tabular}{|c|c|c|c|}
\hline \multirow{2}{*}{ Tahun } & \multicolumn{3}{|c|}{ Jumlah Kunjungan } \\
\cline { 2 - 4 } & Perawatan & Pembelian Produk & Total Kunjungan \\
\hline 2015 & 852 & 1.272 & 2.124 \\
\hline 2016 & 874 & 1.463 & 2.337 \\
\hline 2017 & 804 & 1.211 & 2.015 \\
\hline 2018 & 773 & 1.181 & 1.954 \\
\hline
\end{tabular}

Sumber: Data Olahan 2020

Produk perawatan wajah
yang disediakan pada klinik kecantikan berupa Paket cream untuk perawatan, produk-produk kecantikan, facial treatment, facial detox, setrika wajah, tanam benang, akupuntur, dan perawatan-perawatan kecantikan lainnya. Menurut Kotler (2009:7) harga adalah sejumlah uang yang mempunyai nilai tukar untuk memperoleh keuntungan dari memiliki atau menggunakan suatu produk atau jasa. Harga merupakan bauran pemasaran yang bersifat fleksibel dimana suatu harga akan stabil dalam jangka waktu tertentu tetapi dalam seketika harga dapat meningkat atau menurun.

Promosi adalah kegiatan mengkomunikasikan informasi dari penjualan kepada konsumen atau pihak lain dalam saluran penjualan untuk mempengaruhi sikap dan prilaku. Felisa Skin Care selama ini telah melakukan promosi dengan menggunakan beberapa media, diantaranya (1). Periklanan melalui Media Sosial (Facebook Ads dan Instagram), (2). Promosi Harga pada hari - hari besar ataupun momen tertentu, serta (3). Melakukan Promosi langsung melalui bazar dan stand promosi pada berbagai momen dan kegiatan.

Place (Saluran distribusi) menurut Kotler dalam Wandi $(2016 ; 16)$ “ terdiri dari seperangkat lembaga yang melakukan segala (fungsi) yang digunakan untuk menyalurkan produk dan status pemiliknya dari produsen ke konsumen".Dari defenisi diatas dapat diartikan bahwa saluran distribusi suatu barang adalah keseluruhan kegiatan atau fungsi untuk memindahkan produk disertai dengan hak pemiliknya dari produsen ke konsumen akhir atau pengguna.

Tabel 2 Daftar Produk dan Prawatan yang terdapat pada Felisa Skin Care

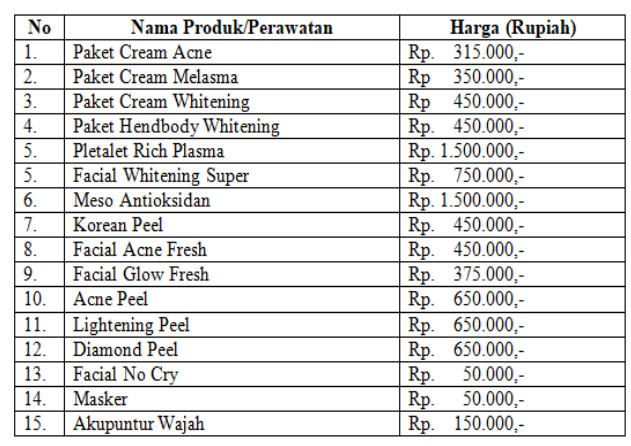

Sumber: Data Olahan 2020

Klinik Kecantikan Felisa Skin Care memberikan beraneka ragam produk untuk bisa dipilih oleh konsumen, hal ini dikarenakan banyaknya pesaing yang memberikan inovasi-inovasi baru. Untuk itu Klinik Kecantikan Felisa Skin Care memberikan pembauruan 
produk agar konsumen juga bisa merasakan kepuasan didalam mengunakan pruduk ini. Penyebaran Konsumen Felisa Skin Care hingga saat ini, tidak hanya sebatas pada daerah kabupaten Indragiri Hulu, akan tetapi telah mencpai Indragiri Hilir dan Kuantan Singingi. Untuk mempermudah pendistribusian Produk dan Jasa untuk pelanggan serta pengembangan usaha, Felisa Skin Care di tahun 2016 membuka satu cabang di Belilas, Kecamatan Seberida Kabupaten Indragiri Hulu.

People (Participant) adalah karyawan penyedia jasa layanan maupun penjualan, atau orang-orang yang terlibat secara langsung maupun tidak langsung dalam proses layanan itu sendiri. Dalam hal ini, terdapat 11 Orang pegawai di Felisa Skin Care yang terdiri atas 2 (dua) Orang Dokter, 7 (tujuh) orang perawat/Beatcion, 1 (satu) orang Marketing, dan 1 (satu) orang Administrasi. Hingga saat ini, terdata sebanyak 1.123 orang pasien Felisa Skin Care, dengan rata-rata kunjungan perbulan sebanyak 130 Orang/bulan.

Proses adalah kegiatan yang menunjukan bagaimana pelayanan diberikan kepada konsumen selama melakukan pembelian barang. Pengelola Klinik Kecantikan Felisa Skin Care sering melakukan berbagai macam bentuk pelayanan dengan tujuan untuk menarik konsumen. Fasilitas Jasa Konsultasi gratis, Konsul langsung setiap saat dengan Dokter melalui WA untuk pelanggan, Kemudahan Transaksi, Member card, dan ketersediaan fasilitas layanan lainnya diharapkan mampu untuk meningkatkan Image Perusahaan.

Dengan penerapan strategi bauran pemasaran jasa yang tepat, maka diharapkan akan mampu pelanggan Felisa Skin Care. Dimana pada dasarnya, tujuan dari suatu bisnis adalah untuk menciptakan kepuasan di kalangan pelanggan/konsumen. Menurut Kotler (2009;79), Kepuasan merupakan tingkat perasaan dimana seseorang menyatakan hasil perbandingan atas kinerja produk barang atau jasa yang diterima dan yang diharapkan. Tingkat kepuasan sangat subyektif, dimana ukuran kepuasan suatu konsumen dengan konsumen lain akan berbeda. Hal ini disebabkan oleh beberapa faktor seperti umur, pekerjaan, pendapatan, pendidikan, jenis kelamin, kedudukan sosial, tingkat ekonomi, budaya, sikap mental dan kepribadian.

Terciptanya kepuasan konsumen dapat memberikan beberapa manfaat , diantaranya hubungan antara perusahaan dan konsumen menjadi harmonis, memberikan dasar yang baik bagi pembelian ulang dan terciptanya loyalitas konsumen, dan membentuk suatu rekomendasi dari mulut ke mulut yang menguntungkan perusahaan.

Loyalitas Pelanggan merupakan keadaan yang sangat diharapkan oleh setiap perusahaan. Tingginya loyalitas pelanggan dapat mengindikasikan keberhasilan sebuah perusahaan. Loyalitas Pelanggan didefenisikan sebagai keinginan yang kuat dari pelanggan untuk membeli kembali produk atau jasa dan tidak akan berpindah ke perusahaan lain. Pelanggan yang loyal akan selalu melakukan pembelian ulang dikemudian hari, jika mereka membutuhkan poduk atau jasa yang sama. 
Konsep Loyalitas merupakan konsep dasar dalam memahami hubungan pemasaran. Karena pada hakekatnya loyalitas berkaitan dengan faktor internal dalam setiap diri perusahaan. Bagi perusahaan memandang arti penting loyalitas adalah merupakan perwujudan moral yang positif dari pelanggan terhadap perusahaan. Hal tersebut bisa dibuktikan dengan banyaknya penelitian pada perusahaan saat ini yang meneliti dan terus mencari cara guna mendapatkan loyalitas dari konsumen (Supranto, 2002).

Hesti Budiwati

(2012)

mengatakan bahwa implementasi Marketing Mix yang terdiri dari Produk, Tempat/lokasi, Promosi dan Harga mempunyai pengaruh yang signifikan terhadap Kepuasan Konsumen. Hasil penelitian Edwin (2013) juga menjelaskan bahwa Bauran Pemasaran yang terdiri dari Produk, Harga, Promosi dan Tempat secra simultan berpengaruh signifikan terhadap kepuasan onsumen. Hal ini bertentangan dengan penelitian yang dilakukan Malardi dan Devilia (2015) yang menyatakan bahwa Pengaruh bauran pemasaran Jasa terhadap kepuasan konsumen dengan hasil Produk, Tempat, Orang, dan Proses secara parsial memiliki pengaruh yang signifikan terhadap kepuasan konsumen, seadangkan Promosi, harga dan bukti fisik tidak memiliki pengaruh yang signifikan terhadap kepuasan Konsumen. Penelitian yang dilakukan oleh Citrawati (2014) pada penelitian Pengaruh Bauran Pemasaran Jasa terhadap kepuasan konsumen dengan hasil Harga dan Promosi berpengaruh negativ terhadap kepuasan Pelanggan. Penelitian Nikel (2009) mengatakan bahwa harga dan produk secara parsial berpengaruh negatif terhadap kepuasan pelanggan.

Berdasarkan latar belakang masalah diatas, maka penulis merumuskan masalah dalam penelitian ini adalah sebagai berikut:

1. Apakah bauran pemasaran berpengaruh terhadap kepuasan pelanggan?

2. Apakah bauran pemasaran berpengaruh terhadap loyalitas pelanggan?

3. Apakah kepuasan pelanggan berpengaruh terhadap loyalitas pelanggan?

4. Apakah bauran pemasaran berpengaruh terhadap loyalitas pelanggan melalui kepuasan pelanggan?

\section{KERANGKA TEORI}

\section{Loyalitas Pelanggan}

Loyalitas Pelanggan di defenisikan Oliver dalam Sangadji dan Sopiah (2013:104) adalah komitmen pelanggan bertahan secara mendalam untuk berlangganan kembali atau melakukan pembelian ulang produk atau jasa terpilih secara konsisten dimasa yang akan datang, meskipun pengaruh situasi dan usaha-usaha pemasaran mempunyai potensi untuk menyebabkan perubahan prilaku.

$$
\text { Griffin dalam }
$$

Sangadji dan Sopiah (2013:104) menyatakan bahwa loyality is defined as non random purchase expressed over time by some decision making unit. Berdasarkan defenisi tersebut dapat dijelaskan bahwa loyalitas lebih mengacu pada wujud prilaku dari unit-unit pengambil keputusan untuk 
melakukan pembelian secara terus menerus terhadap barang atau jasa dari suatu perusahaan yang dipilih.

\section{Kepuasan Pelanggan}

Menurut Zeithaml dan Bitner dalam Sopiah dan Sangadji (2013:180), kepuasan konsumen merupakan “customer's evaluation of a product or service in terms of whether that product or service has met their nees and expactation."Konsumen yang merasa puas pada produk /jasa yang dibeli dan digunakannya akan kembali menggunakan Jasa/produk yang ditawarkan. Hal ini akan membangun kesetiaan konsumen.

Menurut Kotler dalam Arta (2019:20) kepuasan adalah suatu perasaan senang atau kecewa seseorang yang timbul setelah membandingkan antara kesannya terhadap kinerja (hasil) suatu produk atau jasa dan harapnnya. Jika kinerja gagal memenuhi ekspektasi, pelanggan akan merasa tidak puas.

\section{Bauran Pemasaran}

Pemasaran pada saat ini mempunyai peranan penting dalam suatu perusahaan di mana telah terjadi perubahan dalam suatu lingkungan bisnis yang menyebabkan perusahaan harus selalu menyesuaikan strategi. Strategi ini digunakan agar keadaan suatu perusahaan akan menjadi lebih baik dalam memenuhi kepuasan pelanggan.

Pemasaran membutuhkan suatu program atau rencana pemasaran dalam melaksanakan kegiatannya guna mencapai tujuan yang diinginkan oleh perusahaan. Program pemasaran tersebut terdiri dari sejumlah keputusan tentang bauran alat pemasaran disebut bauran pemasaran yang lebih dikenal dengan marketing mix. Bauran pemasaran juga merupakan kebijakan yang digunakan pada perusahaan untuk mampu memasarkan produknya dan mencapai keuntungan.

Hal ini seperti yang disampaikan oleh Kotler (2012:49) adalah : "Marketing mix is the set of marketing tools that the firm uses to pursue it's marketing objectives in the target market". Bauran pemasaran merupakan sekumpulan alat pemasaran (marketing mix) tersebut digunakan oleh perusahaan untuk mencapai tujuan pemasarannya dalam pasar sasaran. Sedangkan menurut Mc Carthy dalam Kotler (2014:17) mengklarifikasi alat pemasaran itu menjadi 4 kelompok yang disebut dengan 4P dalam pemasaran yaitu: produk (product), harga (price), tempat (place),dan promosi (promotion). Adapun bauran pemasaran menurut Zeithaml and Bitner (2013:87) sebagai berikut : "Marketing mix defined as the elemens an organizations controls that can be used to satisfy or communicate with customer. These elements appear as core decisions variables in any marketing text or marketing plan". Bauran pemasaran adalah elemen pada organisasi perusahan yang mengkontrol dalam melakukan komunikasi dengan konsumen atau dipakai untuk mencapai kepuasan konsumen. 


\section{Kerangka Berfikir}

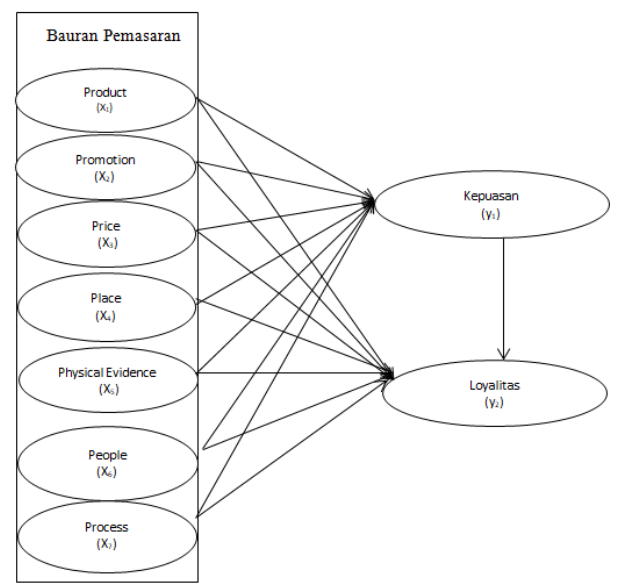

\section{Gambar 1 \\ Model Penelitian}

Sumber: Utari (2010)

\section{Hipotesis}

Berdasarkan perumusan masalah yang telah dipaparkan, maka dapat dirumuskan hipotesis sebagai berikut :
1. Terdapat pengaruh bauran pemasaran terhadap kepuasan pelanggan.
2. Terdapat pengaruh bauran pemasaran terhadap loyalitas pelanggan.
3. Terdapat pengaruh kepuasan pelanggan terhadap loyalitas pelanggan
4. Terdapat pengaruh bauran pemasaran terhadap loyalitas pelanggan melalui kepuasan pelanggan.

\section{METODE PENELITIAN \\ Lokasi dan Waktu}

Penelitian ini dilaksanakan di dua Cabang Klinik Kecantikan Felisa Skin Care di Kabupaten Indragiri Hulu ( Kecamatan Rengat dan
Kecamatan Seberida). Kecamat Rengat merupakan Ibukota Kabuaten Indragiri Hulu, yang mayoritas penduduknya bekerja sebagai pedagang dan Pegawai/Karyawan. Kecamatan Seberida merupakan Kecamatan yang terletak Jalur Lintas Timur Sumatra, dengan mayoritas penduduk bekerja di sektor Perkebunan Sawit dan Pedagang.

\section{Populasi dan Sampel}

Dalam penelitian ini digunakan teknik Probalty Sampling dengan menggunakan metode Purposive Sampling. Purposive Sampling adalah pengambilan sampel yang membatasi pada ciri-ciri khusus seseorang yang memberikan informasi yang dibutuhkan. Syarat sampel pada penelitian ini adalah : Jenis Kelamin Wanita, Umur 23 Tahun s.d 40 Tahun, telah berkunjung (Perawatan/membeli produk) ke Felisa Skin Care Minimal 3 Kali. Roscoe (1975) dalam Uma Sukaran (1992) dalam Sujarweni (2015;76) memberikan pedoman penentuan jumlah sampel di antara $30 \mathrm{~s} / \mathrm{d} 500$ elemen.

Jika sampel dipecah lagi ke dalam subsampel (Laki/Perempuan, SD / SLTP / SMU ,dsb), jumlah minimum subsampel harus 30 . Untuk menentukan ukuran sampel dapat menggunakan cara Slovin sehingga jumlah sampel menjadi 221

\section{Jenis dan Sumber Data}

Adapun jenis dan sumber data yang digunakan dalam penelitian ini adalah: data primer dan data sekunder. Data primer yaitu data yang dikumpulkan dan diolah sendiri oleh penulis melalui kuisioner terhadap responden. 


\section{Metode Pengumpulan Data}

Dalam penelitian ini penulis menggunakan teknik pengumpulan data melalui kuisioner Yaitu data didapat dengan cara membuat daftar pernyataan khususnya kepada responden yang merupakan konsumen atau penyewa yang berlangganan produk Indihome untuk memperoleh data yang dibutuhkan.

\section{Uji Validitas}

Merupakan kemampuan dari construct indicator untuk mengukur tingkat keakuratan sebuah konsep. Artinya apakah konsep yang telah dibangun tersebut sudah akurat atau belum. Kalau sudah akurat maka variabel atau construct tersebut dapat dilanjutkan, sedangkan apabila belum akurat maka perlu dilakukan pengujian ulang

\section{Uji Reliabilitas}

Uji reliabilitas dapat dilihat dari nilai Cronbach Alfa, jika nilai cronbach alfa > 0.6 maka kontruk pertanyaan dimensi variabel dinyatakan reliabel. Jika nilai cronbach alfa < 0.6 maka kontruk pertanyaan dimensi variabel dinyatakan tidak reliabel.

\section{Uji Normalitas}

Uji normalitas merupakan suatu pengujian yang bertujuan untuk mengetahui apakah dalam model regresi, variabel pengganggu atau residual memiliki distribusi normal atau tidak. Pengujian normalitas distribusi data populasi dilakukan dengan menggunakan statistik Kolmogorov-Smirnov. Data populasi dikatakan berdistribusi normal jika koefisien Asymp. Sig (2-tailed) lebih besar dari $\alpha=0.05$.

\section{Path Analysis}

Analisis jalur (path analysis) Teknik analisis data yang digunakan adalah analisa jalur (path analysis). Metode path analysis merupakan perluasan dari analisis regresi linear berganda atau analisis jalur adalah penggunaan analisis regresi linear untuk menaksir hubungan kausalitas antar variabel (model causal) yang telah ditetapkan sebelumnya berdasarkan teori (Ghozali, 2007).Path analysis digunakan untuk menganalisis pola hubungan antar variabel dengan tujuan untuk mengetahui pengaruh langsung maupun tidak langsung seperangkat variabel bebas (eksogen) terhadap variabel terikat (endogen).

\section{Uji Hipotesis \\ Uji Koefisien Determinasi $\left(\mathbf{R}^{2}\right)$.}

Koefisien Determinasi $\left(\mathrm{R}^{2}\right)$ digunakan untuk mengukur seberapa jauh kemampuan variabel-variabel dependen. Nilai koefisien determinasi $\left(\mathrm{R}^{2}\right)$ adalah antara nol dan satu. Nilai $R^{2}$ yang kecil berarti kemampuan variabel-variabel independen dalam menjelaskan variabel dependen amat terbatas. Jika koefisien determinasi sama dengan nol, maka variabel independen tidak berpengaruh terhadap variabel dependen.

\section{Uji Signifikansi Parsial}

Untuk pengujian yang kedua adalah guna membuktikan kebenaran dari hipotesis tersebut digunakan pengujian regresi secara parsial untuk mengetahui apakah secara individu, variabel eksogen mempunyai pengaruh nyata atau tidak nyata terhadap variabel endogen. 


\section{Hasil Penelitian dan Pembahasan Uji Validitas}

Uji validitas dilakukan dengan membandingkan nilai $r$ hitung dengan $r$ tabel pada taraf signifikansi $5 \%$. Jika $r$ hitung $>r$ tabel maka alat ukur yang digunakan dinyatakan valid dan sebaliknya, jika $r$ hitung $\leq \mathrm{r}$ tabel maka alat ukur yang digunakan tidak valid. Nilai $r$ tabel dapat diperoleh dengan persamaan $\mathrm{N}-2=$ $221-2=219=0.138$ dan $r$ hitung diperoleh sebagai berikut:

Tabel 3 uji validitas

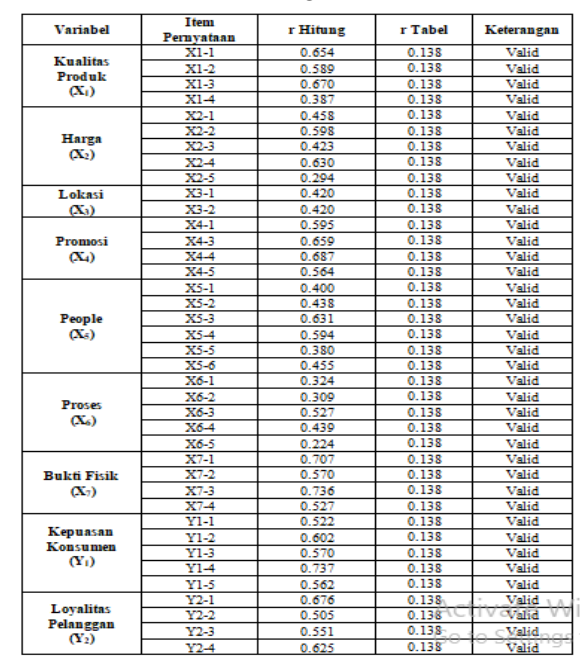

Sumber: Data olahan 2020

Dari Tabel 3 diatas diketahui nilai $r$ hitung seluruh item pernyataan variabel >0,138. Artinya adalah bahwa alat ukur yang digunakan untuk mengukur masing-masing variabel dinyatakan valid.

\section{Uji Reliabilitas}

Sama halnya dengan pengujian validitas, pengujian reabilitas juga dilakukan secara statistik yaitu dengan menghitung besarnya Cornbarh's Alpha. Uji reliabilitas digunakan untuk mengukur suatu kuisoner yang digunakan sebagai indikator dari variabel. Jika koefisien alpha yang dihasilkan $\geq 0,6$, maka indikator tersebut dikatakan reliable atau dapat dipercaya.

Tabel 4 uji Reabilitas

\begin{tabular}{|l|c|c|c|}
\hline \multicolumn{1}{|c|}{ Variabel } & $\begin{array}{c}\text { Cronbach's } \\
\text { Alpha }\end{array}$ & $\begin{array}{c}\text { Kriteria/Nilai } \\
\text { Batas }\end{array}$ & Keterangan \\
\hline Produk & 0.764 & 0.60 & Reliabel \\
\hline Harga & 0.717 & 0.60 & Reliabel \\
\hline Distribusi & 0.691 & 0.60 & Reliabel \\
\hline Promosi & 0.809 & 0.60 & Reliabel \\
\hline People & 0.743 & 0.60 & Reliabel \\
\hline Proses & 0.795 & 0.60 & Reliabel \\
\hline Bukti Fisik & 0.810 & 0.60 & Reliabel \\
\hline Kepuasan Konsumen & 0.811 & 0.60 & Reliabel \\
\hline Loyalitas Konsumen & 0.781 & 0.60 & Reliabel \\
\hline
\end{tabular}

Sumber: Data olahan 2020

Dari Tabel 4diatas dapat diketahuin nilai reliabilitas seluruh variabel $\geq 0,6$, Artinya adalah bahwa alat ukur yang digunakan dalam penelitian ini reliable atau dapat dipercaya.

\section{Uji Normalitas}

Uji normalitas bertujuan untuk menguji apakah data yang digunakan dalam model regresi, variabel independent dan variabel dependen atau keduanya telah berdistribusi secara normal atau tidak.

Tabel 5 Uji Normalitas Jalur I

One-Sample Kolmogorov-Smirnov

Test

\begin{tabular}{|ll|r|}
\hline & & $\begin{array}{r}\text { Unstandar } \\
\text { dized } \\
\text { Residual }\end{array}$ \\
\hline $\mathrm{N}$ & Mean & .0000000 \\
Normal & Std. & .67572948 \\
Parameters & \\
& Deviation & \\
Most Extreme & Absolute & .071 \\
Differences & Positive & .071 \\
Kolmogorov-Smirnov Z & -.069 \\
Asymp. Sig. (2-tailed) & 1.061 \\
\end{tabular}

a. Test distribution is Normal.

b. Calculated from data.

Sumber: Data olahan 2020 
Tabel 6 Uji Normalitas Jalur II One-Sample Kolmogorov-Smirnov Test

\begin{tabular}{|c|c|c|}
\hline & & $\begin{array}{c}\text { Unstandardiz } \\
\text { ed Residual }\end{array}$ \\
\hline \multicolumn{2}{|l|}{$\mathrm{N}$} & 221 \\
\hline & Mean & .0000000 \\
\hline Normal & Std. & 1.00373664 \\
\hline \multirow[t]{2}{*}{ Parameters ${ }^{\mathrm{a}, \mathrm{b}}$} & Deviatio & \\
\hline & $\mathrm{n}$ & \\
\hline \multirow{3}{*}{$\begin{array}{l}\text { Most Extreme } \\
\text { Differences }\end{array}$} & Absolute & .046 \\
\hline & Positive & .044 \\
\hline & Negative & -.046 \\
\hline \multicolumn{2}{|c|}{ Kolmogorov-Smirnov Z } & .683 \\
\hline \multicolumn{2}{|c|}{ Asymp. Sig. (2-tailed) } & .739 \\
\hline
\end{tabular}

a. Test distribution is Normal.

b. Calculated from data.

Sumber: Data olahan 2020

Berdasarkan Tabel 5 dan 6 diatas dapat dilihat hasil uji Kolmogorov Smirnov pada kedua model regresi. Nilai tersebut lebih besar dari nilai kritis 0,05 .

\section{Path Analisis}

\section{Pengaruh Bauran Pemasaran terhadap Kepuasan Konsumen}

Tabel 7 Uji T Substuktural Jalur I

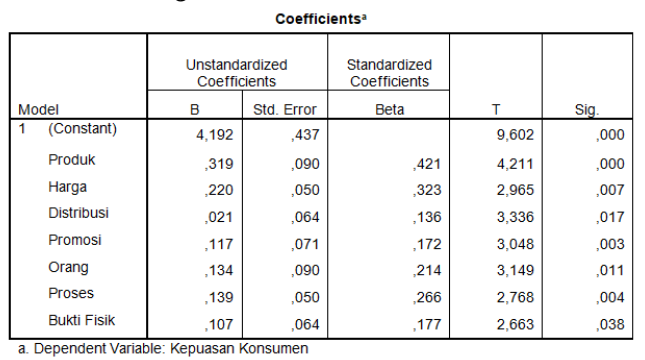

Sumber: Data olahan 2020

Dari Tabel 7 diatas, sehingga dapat dirumuskan persamaan regresi sebagai berikut :

$\mathrm{Y} 1=0,421 \mathrm{X} 1+0,323 \mathrm{X} 2+0,136 \mathrm{X} 3$ $+0,172 \mathrm{X} 4+0,214 \mathrm{X} 5+0,226 \mathrm{X} 6+$ $0,177 \mathrm{X} 7+$ eij
Pengaruh Bauran Pemasaran dan Kepuasan Konsumen terhadap Loyalitas Pelanggan

Tabel 8 Uji T Substuktural Jalur

\begin{tabular}{|c|c|c|c|c|c|}
\hline \multirow[b]{2}{*}{ Model } & \multicolumn{2}{|c|}{$\begin{array}{c}\text { Unstandardized } \\
\text { Coefficients }\end{array}$} & \multirow{2}{*}{$\begin{array}{c}\text { Standardized } \\
\text { Coefficients }\end{array}$} & \multirow[b]{2}{*}{$T$} & \multirow[b]{2}{*}{ Sig. } \\
\hline & B & Std. Error & & & \\
\hline 1 (Constant) & 4,248 & ,778 & & 5,459 &, 000 \\
\hline Produk &, 209 & .134 & .474 & 3,808 & .002 \\
\hline Harga & , 143 & ,074 & ,247 & 2,924 &, 006 \\
\hline Distribusi & ,073 & 095 & ,077 & 4,765 & ,014 \\
\hline Promosi & .012 & , 106 & ,207 & 3,111 & , 012 \\
\hline Orang & , 154 & , 134 & , 102 & 2,852 & ,003 \\
\hline Proses & . 184 & , 075 & ,290 & 3,120 & .003 \\
\hline Bukti Fisik & ,298 & 096 & ,310 & 3,098 & .002 \\
\hline $\begin{array}{l}\text { Kepuasan } \\
\text { Konsumen }\end{array}$ & 280 & 102 & 313 & 5,764 & 001 \\
\hline
\end{tabular}

Sumber: Data olahan 2020

Dari Tabel 8 diatas, sehingga dapat dirumuskan persamaan regresi sebagai berikut :

$\mathrm{Y} 2=0,474 \mathrm{X} 1+0,247 \mathrm{X} 2+0,077 \mathrm{X} 3$ $+0,207 \mathrm{X} 4+0,102 \mathrm{X} 5+0,290 \mathrm{X} 6+$ $0,310 X 7+0,4313 \mathrm{Y} 1+$ eij.

\section{Uji Koefisien Determinasi $\left(\mathbf{R}^{\mathbf{2}}\right)$}

Analisis determinasi digunakan untuk mengetahui persentase sumbangan pengaruh variabel independen secara simultan terhadap variabel terikat.

\section{Uji Koefisien Determinasi Jalur I} Model Summary ${ }^{b}$

\begin{tabular}{|c|c|c|c|c|}
\hline & $\mathrm{R}$ & $\begin{array}{c}\mathrm{R} \\
\text { Square } \\
\end{array}$ & $\begin{array}{c}\text { Adjusted } \\
\text { R } \\
\text { Square }\end{array}$ & $\begin{array}{l}\text { Durbin- } \\
\text { Watson }\end{array}$ \\
\hline 1 & $.615^{\mathrm{a}}$ &, 562 &, 501 & 1,889 \\
\hline
\end{tabular}

a. Predictors: (Constant), Bukti Fisik, Produk, Promosi, Harga, Proses, Orang, Distribusi

b. Dependent Variable: Kepuasan Konsumen Sumber: Data olahan 2020 
Uji Koefisien Determinasi Jalur II Model Summary ${ }^{b}$

\begin{tabular}{|c|c|c|c|c|}
\hline Model & $\mathrm{R}$ & $\begin{array}{c}\mathrm{R} \\
\text { Square }\end{array}$ & $\begin{array}{c}\text { Adjusted } \\
\text { R } \\
\text { Square }\end{array}$ & $\begin{array}{l}\text { Durbin- } \\
\text { Watson }\end{array}$ \\
\hline 1 & $.831^{\mathrm{a}}$ &, 682 &, 568 & 1,273 \\
\hline
\end{tabular}

a. Predictors: (Constant), Kepuasan

Konsumen, Produk, Harga, Orang, Promosi,

Proses, Bukti Fisik, Distribusi

b. Dependent Variable: Loyalitas Konsumen

Sumber: Data olahan 2020

\section{Penutup}

\section{Simpulan}

Penelitian ini bertujuan untuk mengetahui pengaruh bauran pemasaran jasa terhadap keputusan dan kepuasan pelanggan indihome di kabupaten siak. Berdasarkan hasil analisis yang telah dilakukan maka berikut adalah kesimpulan yang diberikan.

1. Produk berpengaruh terhadap kepuasan konsumen, semakin baik produk klinik Kecantikan Felisa Skin Care yang ditawarkan perusahaan maka akan meningkatkan kepuasan pelanggan.

2. Harga berpengaruh terhadap kepuasan konsumen, semakin sesuai harga yang ditawarkan terhadap klinik Kecantikan Felisa Skin Care yang menberikan harga sesuai dengan kebutuhan maka akan meningkatkan kepuasan pelanggan.

3. Lokasi berpengaruh terhadap kepuasan konsumen, semakin luas jangkauan lokasi klinik Kecantikan Felisa Skin Care maka akan semakin meudah konsumen untuk menjangkau lokasi sehingga akan memberikan kepuasan terhadap dirinya.
4. Promosi berpengaruh terhadap kepuasan konsumen, semakin sering perusahaan melakukan Promosi maka akan meningkat kepuasan konsumen untuk melakukan perawatan pada klinik Kecantikan Felisa Skin Care.

5. People berpengaruh terhadap kepuasan konsumen, semakin baik pelayanan yang diberikan dalam memasarkan produk maka akan meningkat kepuasan konsumen untuk melakukan perawatan pada klinik Kecantikan Felisa Skin Care.

6. Proses berpengaruh terhadap kepuasan konsumen, semakin baik yang dilakukan maka akan meningkat kepuasan konsumen untuk melakukan perawatan pada klinik Kecantikan Felisa Skin Care.

7. Bukti Fisik berpengaruh terhadap kepuasan konsumen, semakin baik bukti fisik maka akan meningkat kepuasan konsumen untuk melakukan perawatan pada klinik Kecantikan Felisa Skin Care.

8. Produk berpengaruh terhadap loyalitas konsumen, semakin baik produk klinik Kecantikan Felisa Skin Care yang ditawarkan perusahaan maka akan meningkatkan kepuasan konsumen untuk melakukan pembelian terhadap produk klinik Kecantikan Felisa Skin Care.

9. Harga berpengaruh terhadap loyalitas konsumen, semakin terjangkau harga yang ditawarkan perusahaan terhadap klinik Kecantikan Felisa Skin Care maka akan meningkatkan keinginan konsumen untuk melakukan pembelian pada klinik Kecantikan Felisa Skin Care. 
10. Lokasi berpengaruh terhadap loyalitas konsumen, semakin luas jangkauan lokasi klinik Kecantikan Felisa Skin Care maka akan meningkatkan minat konsumen untuk melakukan perawatan pada klinik Kecantikan Felisa Skin Care.

11. Promosi berpengaruh terhadap loyalitas konsumen, semakin sering perusahaan melakukan Promosi maka akan meningkat minat konsumen untuk melakukan perawatan pada klinik Kecantikan Felisa Skin Care.

12. People berpengaruh terhadap loyalitas konsumen, semakin baik sumber daya manusia dalam memasarkan produk maka akan meningkat minat konsumen untuk melakukan perawatan pada klinik Kecantikan Felisa Skin Care.

13. Proses berpengaruh terhadap loyalitas konsumen, semakin baik yang dilakukan maka akan meningkat minat konsumen untuk melakukan perawatan pada klinik Kecantikan Felisa Skin Care.

14. Bukti Fisik berpengaruh terhadap loyalitas konsumen, semakin baik bukti fisik maka akan meningkat minat konsumen untuk melakukan perawatan pada klinik Kecantikan Felisa Skin Care.

15. Kepuasan konsumen berpengaruh signifikan terhadap loyalitas konsumen, semakin sering konsumen melakukan pembelian mengindikasikan bahwa konsumen merasa loyal terhadap klinik Kecantikan Felisa Skin Care.

16. Produk berpengaruh terhadap loyalitas konsumen dan dimediasi oleh kepuasan konsumen. Semakin baik produk yang diberikan oleh perusahaan makan akan semakin puas konsumen sehingga akan loya terhadap perusahaan.

17. Harga berpengaruh terhadap loyalitas konsumen dan dimediasi oleh kepuasan konsumen semakin terjangkau harga yang ditawarkan perusahaan terhadap klinik Kecantikan Felisa Skin Care maka akan meningkatkan keinginan kepuasan konsumen untuk melakukan pembelian ulang dan loyal terhadap klinik Kecantikan Felisa Skin Care .

18. Lokasi berpengaruh terhadap loyalitas konsumen dan dimediasi oleh kepuasan konsumen semakin luas jangkauan lokasi klinik Kecantikan Felisa Skin Care maka akan meningkatkan kepuasan konsumen untuk melakukan perawatan pada klinik Kecantikan Felisa Skin Care.

19. Promosi berpengaruh terhadap loyalitas konsumen dan dimediasi oleh kepuasan konsumen semakin sering perusahaan melakukan Promosi maka akan meningkat kepuasan konsumen untuk melakukan perawatan pada klinik Kecantikan Felisa Skin Care sehingga akan loyal terhadap promosi yang ditawarkan oleh perusahaan.

20. People berpengaruh terhadap loyalitas konsumen dan dimediasi oleh kepuasan konsumen semakin baik pelayanan yang diberikan terhadap konsumen akan 
semakin puas sehingga akan loyal terhadap perusahaan.

21. Proses berpengaruh terhadap loyalitas konsumen, semakin baik proses yang diberikan maka akan meningkat loyalitas konsumen untuk melakukan perawatan pada klinik Kecantikan Felisa Skin Care.

22. Bukti Fisik berpengaruh terhadap loyalitas konsumen dan dimediasi oleh kepuasan konsumen semakin baik bukti fisik maka akan meningkat kepuasan konsumen untuk melakukan perawatan dan loyal terhadap klinik Kecantikan Felisa Skin Care.

\section{Saran}

Berdasarkan keterbatasan di atas, maka dapat disampaikan beberapa saran yaitu sebagai berikut:

1. Promosi memiliki pengaruh paling rendah terhadap loyalitas konsumen. Dengan demikian diharapkan kepada perusahaan agar meningkatkan promosi klinik Kecantikan Felisa Skin Care misalnya melakukan promosi langsung hingga ke daerah-daerah. Dengan demikian diharapkan kepuasan dan loyalitas konsumen akan meningkat.

2. Perusahaan harus meningkatkan produk keunggulan produk klinik Kecantikan Felisa Skin Care dengan cara meningkatkan kualitas produk yang ditawarkan sesuai dengan kebutuhan konsumen.

3. Perusahaan harus menyesuaikan harga yang dibayarkan konsumen dengan manfaat yang mereka terima lebih bervariasi dengan cara memberikan banyak pilihan variasi produk beserta manfaatnya.

4. Manajemen perusahaan harus memperhatikan penyebaran produk agar mudah ditemukan konsumen saat mencarinya.

5. Perusahaan harus melakukan promosi peroduk dengan baik misalnya melakukan iklan melalui televisi, internet dan media lainnya sehingga iklan tersebut maksimal.

6. Perusahaan harus lebih melatih staf agar mampu memberikan yang terbaik kepada konsumen. Misalnya melakukan pelayanan dengan cepat dan akurat.

7. Perusahaan harus mengupayakan memberi kemudahan dan kecepatan dalam proses transaksi dengan cara memberikan informasi yang jelas mengenai prosedur perawtan sehingga dapat diselesaikan dengan cepat.

\section{Daftar Pustaka}

Griffin, Jill. 2009. Customer Loyalty : How to Learn It, How to Keep It. Erlangga, Jakarta.

Hasan, Ali. 2013. Marketing dan Kasus-kasus pilihan .CAPS. Yogyakarta.

Kondasani Rama Koteswara Rao, Panda Rajeev Kumar . 2015 , " Customer perceived service quality, satisfaction and loyalty ini Indian Private healthcare ", International Journal of Health Care Quality Assurance, Vol 28 Issue : 5 pp. 452 - 467. 
Kotler, Philip, 2009. Manajemen Pemasaran, Erlangga, Jakarta.

Mulkan, Rambah Satria (2016). Pengaruh Bauran Pemasaran Jasa Terhadap Nilai Pelanggan dan Keputusan Konsumen Memilih Griya iB Hasanah BNI Syariah Cabang Pekanbaru . Universitas Riau. Tesis

Sangadji, E. M \& Sopiah. 2013. Consumer Behavior :

Perilaku Konsumen dan Strategi Pemasaran Jilid 2. Jakarta : Erlangga.

Sangadji, E. M \& Sopiah. 2013. Perilaku Konsumen : Pendekatan Praktis Disertai : Himpunan Jurnal Penelitian. Andi Yogyakarta Yogyakarta.

Sujarweni, Wiratna (2015) “ Metodologi Penelitian Bisnis dan Ekonomi.Yogyakarta : Pustaka Baru Press

Wandi, Surya. (2016). Analisis Pengaruh Bauran Pemasaran Jasa Terhadap Keputusan Memilih Kredit dan Kepuasan Nasabah pada BPR di Kabupaten Kampar (Studi Kasus di Kecamatan Siak Hulu . Universitas Riau. Tesis 